\title{
8 \\ Thinking of Art as Informal Life Politics in Hong Kong
}

\author{
Olivier Krischer
}

\section{Towards a Language of Social Action}

This chapter considers artistic practices as a form of informal life politics in the context of Hong Kong, through the case of the Wooferten 活化廳 art space. Besides situating the space's emergence in the context of local cultural politics, and a 'translocal' network of regional collaborators, I also consider theoretical approaches to this form of creative action, and relate them to the often overlooked history of social movements in Hong Kong.

The challenge of thinking about collective social actions or movements in Hong Kong became clearer to me after being invited to present at a symposium organised by ZKM (Zentrum für Kunst und Medientechnologie), Germany, in January 2014, titled 'Global Activism Symposium'. ${ }^{1}$ The roster of speakers was inspiring yet also revealing, including members of Occupy Wall Street, an activist turned politician from Iceland's Pirate Party, street artists and journalists from

1 'Global Activism Symposium' was held at ZKM Centre for Art and Media Karlsruhe from 24-26 January 2014, coinciding with the exhibition Global Activism. For details of presentations and speakers, see www.global-activism.de/global-activism-symposium. 
the Egyptian and Tunisian uprisings, a South African ANC (African National Congress) veteran turned academic, American direct democracy advocates, and some artists working with 'radical' political groups. ${ }^{2}$

Although I had introduced a number of participants from Hong Kong when approached by the organisers, they eventually came back to ask if I would speak on their behalf. I found it awkward situating the range of actions and motivations from Hong Kong and other urban contexts in East Asia, each with their own particular history and epistemology, into a politics of 'global activism'. ${ }^{3}$ The so-called Umbrella protests would not occur until September of that year, and I don't recall anyone at the symposium showing awareness of Hong Kong's own Occupy Central movement. ${ }^{4}$ There was, of course, traffic in creative ideas between people facing similar pressures of the neoliberal urban economy, but the different facets of Hong Kong politics, its history and 'post-colonial but not independent' reality, seemed a world away. While I could introduce these informal sites of creative action on the other side of the world, I was afraid they would be lost in translation. Did I even know the words to make sense of them myself? Reflecting on this brings to mind the words of another border-crossing artist:

If the language I used failed to deliver, was I to appropriate another that talked to others even though it did not talk to me? How would a universal language work when the spaces in which we dwell are not synchronised?

2 The latter refers to the New World Summit, a project established by Dutch artist Jonas Staal, as a series of 'summits' for political organisations that have been outlawed by the governments under which they live (typically as 'terrorists'), pointing to the limits of 'democracy'. The first summit, held at the Berlin Biennale in January 2014, included representations by the Kurdish Women's Movement, the Basque Independence Movement, the National Liberation Movement of Azawad and the National Democratic Front of the Phillipines. See www.newworldsummit.eu.

3 I also found it awkward speaking on behalf of a wide group of artists whom I had discussed with organisers with the intention of their participation, rather than my own. I suspect that had the Umbrella protests of September 2014 occurred before the exhibition and symposium, participation by Hong Kong artists and activists would have been sought.

4 Part of the spread of 'Occupy' actions following Occupy Wall Street, Occupy Central was an occupation under the HSBC bank headquarters, in Central, Hong Kong, initiated 15 October 2011 and forcibly evicted on 11 September 2012.

5 Phaptawan Suwannakudt, 'Catching the Moment, One Step at a Time', in F. Nakamura, M. Perkins and O. Krischer eds, Asia Through Art and Anthropology: Cultural Translation Across Borders (London: Bloomsbury, 2013), 99. 


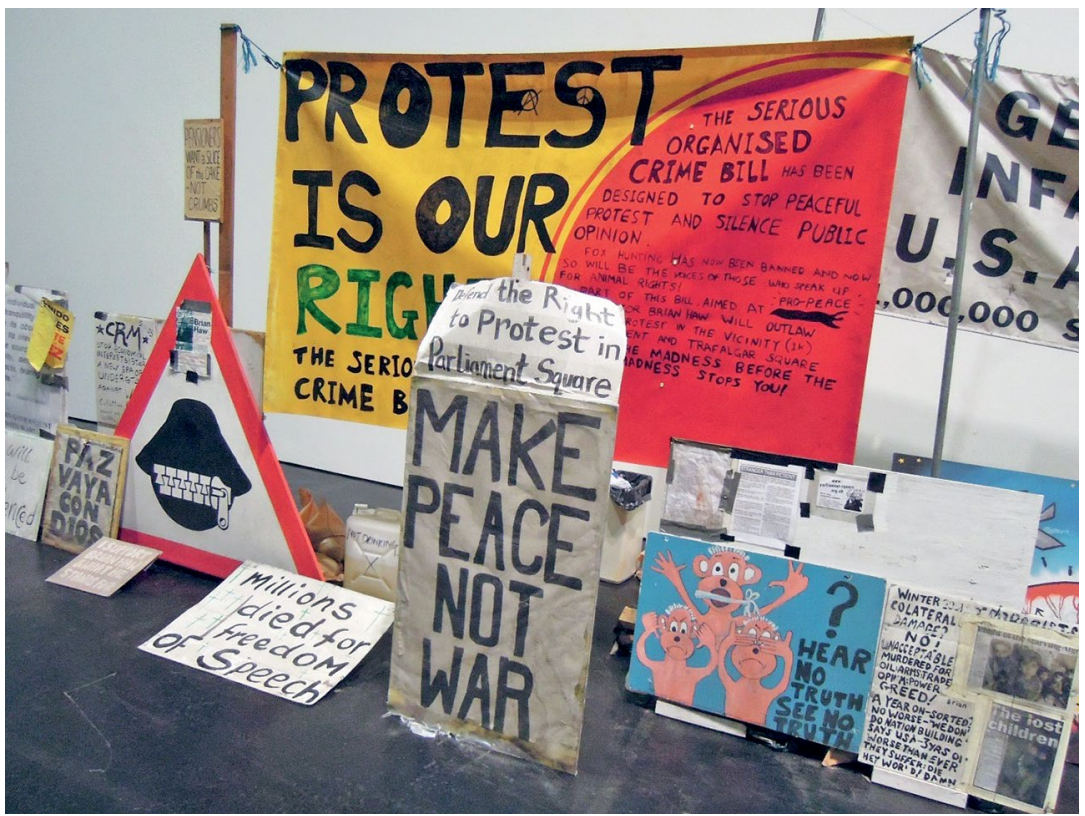

Figure 8: Exhibition view from Global Activism at ZKM Centre for Art and Media, Germany, February 2014. Detail of an artwork by Mark Wallinger, comprising a reconstruction of a 'peace camp' in London's Parliament Square, where activist Brian Haw lived from 2001 until his eviction in 2006, in protest at the UK's participation in wars in Iraq and Afghanistan. In 2007, Wallinger's 'installation' based on Haw's encampment won the prestigious Turner Prize following its exhibition at the Tate Modern.

Source: Olivier Krischer.

How can we talk about collective actions in Hong Kong or East Asia, particularly in cases where networks of collaborators work between formally distinct political systems? Calling for less 'state-centred' understandings of politics, some recent approaches in political science recognise the integral role of 'informal politics' in various East Asian political systems. Ditttmer, Fukui and Lee's Informal Politics in East Asia (2000), for example, focuses on the ways informal actors, particularly kinship groups and factions, work to affect change through formal political institutions, legally or otherwise. ${ }^{6}$ Interestingly, they note how such informal affiliations can predate the institutional systems with which they now negotiate. Examples

6 L. Dittmer, H. Fukui and P. N. S. Lee eds, Informal Politics in East Asia (Cambridge, UK: Cambridge University Press, 2000). This features case studies from Taiwan, China, South Korea, North Korea and Vietnam. 
include the roles of former Route Army factions in China, Kuomintang (KMT) factions in Taiwan, or the oligarchic continuity bridging preand postwar politics in Japan. While sharing certain modes of action, such informal actors operate differently in different political systems. In China, 'submerged networks' might only become apparent during leadership changes or Party crises, whereas elsewhere they have become structural and publicly acknowledged, as in Japan. ${ }^{7}$ While the so-called marketisation of conflicts of interest can decrease violent confrontation, it can also lead to increased corruption. Significantly, the authors point out that such informal, even 'illegal' machinations are often employed to affect legitimate change where formal channels have become difficult or unworkable.

But this analysis remains focused on formal institutions as central agents in societal change. Where Fukui recognises that an appreciation of informal politics means that 'many contemporary social issues are ... neither a priori private and non-political nor a priori public and political', institutions remain the legitimate political agents. ${ }^{8}$ For Dittmer, informal politics 'consists of the use of non-legitimate means (albeit not necessarily illegal) to pursue public ends. Thus it is conceptually sandwiched between formal politics on the one hand and "corruption" on the other. . Despite expanding the notion of politics, this still seems close to the "who gets what, when, and how' approach, in which it remains institutions that author(ise) change in 'public' life. ${ }^{10}$ Informal politics here acts according to the limits of an existing system, even when circumventing it. Moreover, the persistence of such informal channels is attributed to the weak rule of law and weak formal institutions, while institutional democratisation is aligned with economic growth. Accordingly, for Dittmer, Fukui and Lee, the 'logical step' is to form or join institutionalised political parties, which provide more 'civil' means of settling differences. ${ }^{11}$ But what about

7 Lowell Dittmer, 'Conclusion: East Asian Informal Politics in Comparative Perspective', in Dittmer, Fukui and Lee, Informal Politics in East Asia, 298-99.

8 Haruhiro Fukui, 'Introduction: On the Significance of Informal Politics', in Dittmer, Fukui and Lee, Informal Politics in East Asia, 1-20, citation from 8.

9 Dittmer, 'Conclusion: East Asian Informal Politics in Comparative Perspective', 292. Emphasis in the original.

10 See Harold D. Lasswell, Politics: Who Gets What, When, How, reprinted in Harold D. Lasswell,

The Political Writings of Harold D. Lasswell (New York: The Free Press, 1951), 295-461.

11 Dittmer, 'Conclusion: East Asian Informal Politics in Comparative Perspective', 307. 
attempts at redefining a formal system or of acting autonomously of formal structures, either individually or collectively, such as in the form of social movements or citizen collectives?

In the wake of the Paris student movement of May 1968, some European historians and sociologists reconsidered the role of social movements not merely as ephemeral protests but as vehicles of urban change. Building on the work of Alain Touraine, Manuel Castells in particular has theorised the relationship between cities and social change, focusing on civic movements across different times and cultures. ${ }^{12}$ Discussing the Comunidades of Castilla (1520-22), in which citizens allied with nobles against the Spanish monarchy, Castells recognised that citizens acted collectively on the basis of common concerns rather than structural conditions such as social class. ' $[T]$ he comuneros designated their opponents in terms of their monopoly over political institutions and not on the basis of their social privileges. ${ }^{13}$ Castells sees this as representing the underlying structure of social movements in many times and places. This importantly casts social movements and citizen collectives as legitimate historical agents. However, it is sometimes difficult to differentiate between 'movements' and uprisings in Castells' work. In his case studies, people directly seek more equitable political representation by affecting institutional change, or through revolution, which here means the seizure of institutional power. ${ }^{14}$ Even in his more recent work on social movements in the 'Internet age'including civil uprisings in Iceland and North Africa, and the Occupy movement in North America-Castells remains drawn to a dualistic interaction between 'power and counterpower', an 'endless historical process of conflict and bargaining' with institutions that 'regulate peoples' lives'. ${ }^{15}$ While he identifies a fundamental 'battle for the construction of meaning in the minds of the people', Castells seems less concerned with the ways in which people constantly renegotiate such systems

12 Manuel Castells, The City and the Grassroots: A Cross-Cultural Theory of Urban Social Movements (Berkeley: University of California Press, 1983), 291.

13 ibid., 7.

14 The other case studies are the Paris Commune (1871), the Glasgow Rent Strike (1915), the Movimiento Inquilinarios or 'Tenants Union' strike in Veracruz, Mexico (1922-27), and the 'revolt of the American cities' during the 1960s, demanding community control and racial equality in the face of a burgeoning postindustrial society. Hence, in all but the last example what Castells presents as 'movements' essentially took the form of uprisings, as direct and temporary challenges to institutional authority.

15 Manuel Castells, Networks of Outrage and Hope: Social Movements in the Internet Age (Cambridge, UK: Polity, 2012), 5. 
at an individual level too. ${ }^{16}$ What if actors do not form 'the majority', despite collective mobilisation? Or if collectives are tenuous, protracted or intermittent networks of loosely affiliated groups and individuals? How do we recognise collective actions that take the form of ongoing collaborations rather than rallying behind a single cause or principle?

Responding particularly to the anti-nuclear movement of the early 1980 s, Alberto Melucci observed that what he called 'new social movements' had increasingly shifted 'from the "political" form, which was common to traditional opposition movements in Western societies, to cultural ground'. ${ }^{17}$ Melucci felt the very notion of a movement is confined by the limited vocabulary of sociological discourse, which inherits a legacy of dualism from philosophies of history' ${ }^{18}$ and therefore suffers from the 'epistemological challenge' of belonging to the same conceptual framework as 'progress' or 'revolution'. ${ }^{19}$ Understood in this way, social movements are described either in terms of 'breakdown' (collective economic crisis or social disintegration), or 'solidarity' (shared interests within a common structural condition, such as class). This dualism might be expressed in terms of 'structure/motivation', where collective action derives either from the logic of the system (e.g. socioeconomic context) or from personal beliefs (e.g. ideology, values). ${ }^{20}$

Instead, Melucci considered movements or collective actions as social constructions, 'built by an organisational investment'. ${ }^{21}$ By concentrating on 'systemic relationships rather than the logic of actors', he comes to describe movements as 'action systems': a structure that facilitates communication and interdependence among actors, even in apparently loose or temporary circumstances. These systems are dynamic, 'built by aims, beliefs, decisions, and exchanges operating in

16 ibid., 246.

17 Alberto Melucci, 'The Symbolic Challenge of Contemporary Movements', Social Research 52, no. 4 (Winter 1985): 789. For a comparative definition of 'old' and 'new' political paradigms as they are used here, see Claus Offe, 'New Social Movements: Challenging the Boundaries of Institutional Politics', Social Research 52, no. 4 (Winter 1985): 821-32. Briefly, the 'old' paradigm of the postWorld War II period emphasised economic growth and security, keeping civil society at a distance from public policy participation; the 'new' paradigm, writes Offe, is action in a third space that does not conform to the binary public or private of liberal politics. The 'political' here is when both: 1. The actor claims the means of action be recognised as legitimate, and 2 . The ends of action can be recognised by the wider community.

18 Melucci, 'The Symbolic Challenge of Contemporary Movements', 790.

19 ibid., 799.

20 ibid., 790.

21 ibid., 792-3. 
a systemic field'. Collective identity thus becomes less a condition than 'a shared definition' of the plural opportunities and constraints offered by collective action.

Actors in conflicts are increasingly temporary, and their function is to reveal the stakes, to announce to society that a fundamental problem exists in a given area. They have a growing symbolic function; one can probably speak of a prophetic function. They are a kind of new media. They do not fight merely for material goals or to increase their participation in the system. They fight for symbolic and cultural stakes, for a different meaning and orientation of social action. They try to change people's lives; they believe that you can change your life today while fighting for more general changes in society. ${ }^{22}$

Furthermore, Melucci accepted that postindustrial urban life, as it was then emerging, has not only an economic base but also a symbolic and cultural one. Collective action is not carried out simply to exchange goods or increase formal political participation, 'it challenges the logic governing production and appropriation of social resources' ${ }^{23}$ The organisation of such movements is more diffuse, like a network, "informal" relationships connecting core individuals and groups to a broader area of participants and "users" of services and cultural goods produced by the movement'. ${ }^{24}$ Increasingly autonomous, this kind of collective action is a 'point of convergence for different forms of behaviour which the system cannot integrate' - not only for conflict, but also for 'social deviance and cultural innovation'. ${ }^{25}$ The 'movement networks' become systems of exchange, through which people and information circulate, with participation becoming a goal in itself. 'Since action is focused on cultural codes, the form of the movement is a message, a symbolic challenge to the dominant patterns.' In short, by practicing the change they are struggling for, 'they redefine the meaning of social action for the whole society. ${ }^{26}$

\footnotetext{
22 ibid., 797. Emphasis in the original.

23 ibid., 798.

24 ibid., 798-9.

25 ibid., 799.

26 ibid., 801. Melucci developed these ideas into a general theory of collective identity and action in the late 1980s and 1990s, particularly with the increased effect of telecommunications on collective social actions. See Melucci, Nomads of the Present: Social Movements and Individual Needs in Contemporary Society (London: Hutchinson Radius, 1989) and Challenging Codes: Collective Action in the Information Age (Cambridge and New York: Cambridge University Press, 1996). For a comparative discussion of Melucci's work on theories of community as action and collective identity, see Gerard Delanty, Community, 2nd ed. (London; New York: Routledge, 2009), 94-9.
} 


\section{The Politics of Aesthetics}

How does the action of a part symbolically challenge, by its very definition, the meaning of the whole? Bearing some similarity to Melucci's reinterpretation of a movement as a dynamic 'action system', Jacques Rancière's re-reading of aesthetics has had a notable impact on current thinking in both the arts and politics. Rancière sees aesthetics not merely as 'the sensible', but rather as a certain 'modality' through which the sensible is distributed (partagé, literally 'shared'). This derives from Rancière's understanding of the Greek term aesthesis as the capacity both to perceive something and to make sense of it. ${ }^{27}$ This situates politics as emerging from the aesthetic experience itself, because of 'the way in which aesthetic experience-as a refiguration of the forms of visibility and intelligibility of artistic practice and reception-intervenes in the distribution of the sensible'. ${ }^{28}$

To appreciate Rancière's notion of a politics of aesthetics, it is useful to consider his distinction between three 'regimes of identification' in art: the ethical, the poetic and the aesthetic. ${ }^{29}$ In the ethical regime, 'art' is not valued for itself. Rather the origin and purpose of art take precedence. Judgement is based on the extent to which an image, for example, fulfils its function. The poetic regime involves representation, in that the principle of mimesis organises 'ways of doing, seeing, making, judging'. It distinguishes art as such, allowing the identification of imitations and the development of normative principles, which underpin the classical 'fine arts'. By contrast, in the aesthetic regime 'artistic phenomena are identified by their adherence to a specific regime of the sensible, which is extricated from its ordinary connections and is inhabited by a heterogeneous power, the power of a form of thought that has become foreign to itself'. ${ }^{30}$ The aesthetic regime frees art from the rules of subject, material and genre; it removes the 'mimetic barrier' that distinguishes artistic 'ways of doing and making' from other social practices. ${ }^{31}$

27 Jacques Rancière, 'The Aesthetic Dimension: Aesthetics, Politics, Knowledge', Critical Inquiry

36, no. 1 (Autumn 2009): 1.

28 ibid., 5.

29 Jacques Rancière, The Politics of Aesthetics: The Distribution of the Sensible, trans. Gabriel Rockhill (London; New York: Continuum, 2004), 20-4.

30 Rancière, The Politics of Aesthetics, 22.

31 ibid. 
For Rancière, the aesthetic regime is a democratic situation; it is here that politics takes place as such, because for him the demos is not the power of the everyone but rather of 'the whoever'. 'It is the principle of infinite substitutability or indifference to difference, of the denial of any principle of dissymmetry as the ground of the community. ${ }^{32}$ Dissymmetry is a structural inequality, while the democratic 'supplement' represents an inherent capacity to question the perceived or prevailing order of the system. 'This is the aesthetic dimension of politics: the staging of a dissensus - of a conflict of sensory worlds - by subjects who act as if they were the people. ${ }^{33}$ Rancière's concept of politics liberates democracy from the state; it also implies that politics is naturally transgressive-it points to the inherent potential of the political subject whose faculties open to them an aesthetic experience, an 'as if', in which anything is possible (or thinkable). ${ }^{34}$ 'Politics revolves around what is seen and what can be said about it, around who has the ability to see and the talent to speak, around the properties of spaces and the possibilities of time. ${ }^{35}$ It is in this sense of politics as transgressive that we might discover the potential for aesthetic, creative practices to intervene in and redefine the status quo. I think it is also significant that this approach emphasises the staging of politics, the enacting of an 'as if', which (in politics) is a legitimate state of being. This function of metaphorical action is highly relevant to creative forms of activism.

\section{Wooferten: Community, Art and Activism}

An examination of Wooferten in Hong Kong provides an opportunity to explore informal life politics from the perspective of aesthetic practice and metaphorical action. It should also be noted that it is just one example among many different initiatives that have emerged in Hong Kong during the last decade. It was by no means the first artist-run space, nor the first organisation using arts to activate or interrogate ideas of community and local heritage, but it offers a good example of the establishment, development and transformation of a fixed space for artistic and social

32 Rancière, 'The Aesthetic Dimension: Aesthetics, Politics, Knowledge', 10.

33 ibid., 11.

34 This has also more broadly been part of Rancière's attempts to deprivilege philosophy as the exclusive domain of sense-making. See Gabriel Rockhill, 'Translator's Introduction: Jacques Rancière's Politics of Perception', in Jacques Rancière, The Politics of Aesthetics, 2.

35 Rancière, The Politics of Aesthetics, 13. 
experimentation, in years that have seen a flurry of social action. The participation of a younger generation of so-called 'Post-80s' artistactivists has also been significant in Wooferten's experience. ${ }^{36}$

It is difficult to succinctly describe Wooferten, as the nature of the space, its activity and 'management' has evolved in response to both the administrative system under and against which it operates, as well as to the community in and with which it acts. When I first visited, on a balmy Hong Kong night in August 2011, a Japanese activist-artist, Ichimura Misako, was about to start her presentation. Her talk was being translated from Japanese to Cantonese for a crowd of around 20 people-which at Wooferten meant the shopfront space was packed. Ichimura is a homeless artist' and activist who had been invited by the space to spend a couple of weeks in Hong Kong, presenting her work informally while also realising a series of actions locally. These local actions were then photographed and added to documentation she showed as an exhibition. On one wall, painted a vivid red, ran the Japanese words 'Hands off Miyashita Park!', with a megaphone positioned nearby. These seemed like a vignette, reenacted for this Hong Kong audience, from the protests in which Ichimura had been active, against plans by the Nike Corporation to 'sponsor', gentrify and commercialise a Tokyo public park used by homeless people.

Wooferten was established in September 2009 as a non-profit organisation, and successfully applied to operate the Shanghai Street Artspace, administered by the Arts Development Council (ADC).$^{37}$ This old corner shop once operated as a Chinese herbalist until the late 1990s, yet the building belongs to the Hong Kong Government. Around 2000, the government agreed to lease it to the relatively new ADC as a goodwill gesture and made it available for arts projects based on annual competitive applications. For nearly a decade it was used for a variety of

36 Lee Chun Fung 李俊峰, 'Cong bashihou de guandian kan huohuating' [Wooferten, seen from a Post-80s Perspective] 從八十後的觀點看活化廳, in Yuk Hui and DOXA Collective eds, Creative Space: Art and Spatial Resistance in East Asia (Hong Kong: Roundtable Synergy Books, 2014), 214-22. 37 The Hong Kong Arts Development Council is a statutory authority established in 1995 to advise the Hong Kong Government on cultural policy, distribute grants and promote various art forms in the territory. 
small-scale arts programmes, ranging from art education to exhibitions, nominally inspired by the idea of 'community arts', in a renovated whitecube gallery setting. ${ }^{38}$

By 2009, when artist Luke Ching (b. 1972) noticed that the ADC was soliciting applications again, the local art scene, and indeed Hong Kong more generally, had significantly changed; as founding member and inaugural manager Jasper Lau put it, 'people were talking about community'. ${ }^{39}$ Ching, whose pioneering practice actively intervenes in or 'hijacks' parts of city life, ${ }^{40}$ saw an opportunity to focus on artistic process rather than object-making, and to interrogate the idea of community art being touted by the ADC. Ching approached artist friends whose work had engaged with political and social issues; as a result, Wooferten was established as a non-profit arts organisation, with 10 'members', nominally led by Ching and managed by critic-curator Jasper Lau. ${ }^{41}$ The space was intended as a place in the middle of Yau Ma Tei where the community could meet art, and art could meet the local community. Yau Ma Tei is an old Kowloon neighbourhood that now finds itself at the edge of the future West Kowloon Cultural District-a massive, and controversial, HKD80 billion cultural and commercial development announced in 1996-97, designed to realise the Special Administrative Region (SAR) Government's vision of Hong Kong as a 'world city', but which has repeatedly been criticised as a typical top-down project that ignores existing communities, local needs and real cultural diversity. ${ }^{42}$

38 Unless otherwise noted, the following information is based on interviews with founding members Jasper Lau Kin-Wah and Lee Chun Fung (interviewed in Yau Ma Tei, Hong Kong, 19 January 2012) and Luke Ching Chin-Wai (interviewed at Wooferten, in Yau Ma Tei, Hong Kong, 24 October 2013), as well as articles reflecting on Wooferten. See particularly Lee Chun Fung, 'Wooferten', in Alice Ko ed., Reverse Niche: Dialogue and Rebuilding at the City's Edge (Taiwan, 2013), 202-11 [Chinese] and 216-24 [English]. I have generally referred to the Chinese version, as the English is an abridged translation.

39 Interview with Lau, Hong Kong, 19 January 2012.

40 Interview with Luke Ching; see also Lee Chun Fung, 'A Good Idea is Hijack', dated 2 November 2012, translated by Sumyi Li. This was apparently published for the Asia Art Award 2010 in which Ching was nominated. leechunfung.blogspot.com.au/2012/11/a-good-idea-is-to-hijack-it.html.

41 Interview with Lau, Hong Kong, 19 January 2012. The 10 founding members were Luke Ching, Jasper Lau, Kwang Sheung Chi, Doris Wong Wai-ying, Wan Yau, Clara \& Gum Cheung, Cally Yu, Edwin Lai Kin Keung, Law Man Lok and Lee Chun Fung.

42 The West Kowloon Cultural District (WKCD) project is a legacy of Hong Kong's first posthandover Chief Executive, Tung Chee-hwa, and has become a much studied example of post-handover governance issues. See Agnes Shuk-mei Ku, 'Contradictions in the Development of Citizenship in Hong Kong: Governance without Democracy', Asian Survey 49, no. 3 (May/June 2009): 521-4; and Carolyn Cartier, 'Culture and the City: Hong Kong, 1997-2007', The China Review 8, no. 1 (Spring 2008): 66-9. 
Ching's original idea was for Wooferten to be a short-term creative experiment, lasting only one or two years. In the first year, the group developed exhibitions and projects that actively sought to engage with and learn about the surrounding community, not only as an audience for their artwork but as participants, local experts and neighbours—or rather kaifong 街坊, people from the neighbourhood (a Cantonese term that repeatedly appears in Wooferten materials). The project 'Small Small Prize! Big Big Pride!' took the form of a competition where participants were asked to nominate their favourite local shops, for which DIY trophies were made by Wooferten and delivered with fanfare to the winning establishments. Another early project, 'Mastermind', connected artists with the workshops of local craftspeople and technicians, including expert activities outside the typical realm of the arts, such as electrical repairs and locksmithing. Like many of Wooferten's subsequent projects, these were bilateral: Wooferten learnt more about the area and their neighbours, while also sharing skills, resources and local history, and cultivating more trust.

The space often played with the formal concept of an institution to serve new purposes: for example, when they discovered that a flower plaque (faapai 花牌) maker had lost his workshop in nearby Sham Shui Po due to an urban redevelopment project, Wooferten offered him a permanent space at the back of their premises, as an 'Artist in Residence', naming him Wooferten's 'Flower Plaque Master in Residence'. Subsequently, Wong Nai-chung, the flower plaque master, adapted his commercial practice to suit his new circumstances, creating plaques with slogans of protest, as well as making public presentations and demonstrations to raise awareness of this unique local cultural practice, which has been pushed ever further from the city by rising rents and the upscaling of local businesses. Once resident at Wooferten, Wong's work became part of the space's activity; he made a large 'Wooferten' faapai for the shopfront, and later began contributing a regular column to Wooferten's local newsletter, becoming inextricably associated with the space. ${ }^{43}$

43 Ironically, Wong Nai-chung's work has since become better known, while the surge in projects relating to local customs and heritage has also heightened awareness of flower plaques and other local artisanal trades being pressured by urban redevelopment. Jasper Lau has published a slideshow explaining how the government repossessed Wong's shop and home, and his subsequent practice. See 'Flower Plaque (Faa Pai) Craft Master Wong Nai Chung', YouTube video, 6.30, posted by 'kin wah lau', 2013. www.youtube.com/wa tch?v=lu7JftKIHDo, accessed 18 December 2015. 


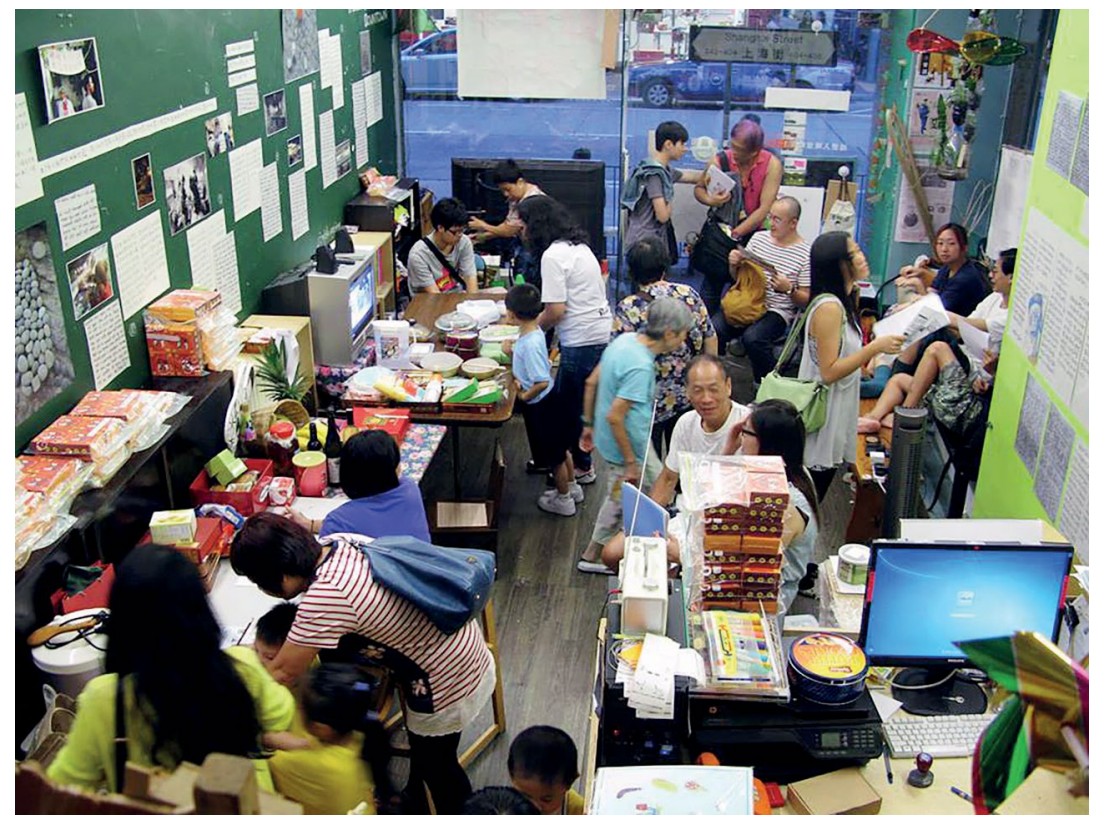

Figure 9: An event at Wooferten in September 2013.

Source: Courtesy of Lee Chung Fung and Wooferten.

Wooferten's development then took a slightly different turn, with management passing to the youngest founding member, Lee Chun Fung. When the ADC seemed poised to take the space back after a year of operation, members deliberated on whether to reapply or to leave. ${ }^{44}$ Lee and a few others chose to carry on developing the space's activities, emphasising a two-pronged approach: continuing to make experimental art projects with community relevance, while also promoting the gallery space as an informal community centre, providing amenities such as a water fountain, comfortable sofa and public computer, even posting a sign on the door that invited locals to drop by 'anytime'. Local children (including those of South Asian migrant working families in the area) stop by after school; some elderly neighbours, even volunteers from other parts of Hong Kong, started dropping in to take part in whatever was happening and to propose their own projects. This 'living room' indeed seems to be reflected in the organisation's name: 'Wooferten' is an

44 Jasper Lau and Lee Chung Fung, interview by author, digital recording, Hong Kong, 19 January 2012; also see Lee Chung Fung 'Wooferten', in Lee Chung Fung ed., Wooferten's Art/Activist in Residence (AAIR) 2011-12, (Hong Kong: Wooferten, 2014), 129. 
alternative, slightly Anglophone-looking transliteration of the Cantonese words wut faa teng, suggesting a 'hall' or place (teng 廳) for 'activation or revitalisation' (wut faa 活化). ${ }^{45}$

\section{Lee Chun Fung and Art Activism}

Born in 1984, Lee identifies as a member of Hong Kong's 'Post-80s' generation, those who came of age in the late 1990s to mid-2000s, the first decade of People's Republic of China (PRC) rule, in which issues of Hong Kong values and identity progressively came to the fore. ${ }^{46}$ After graduating in fine arts from the Chinese University of Hong Kong, Lee worked with the Artist Commune, another community-oriented non-profit arts organisation, established in 1997 and located in the Cattle Depot Artists Village—a repurposed heritage building also administered by the ADC. Why this interest in community? One notable turning point is the year 2003, marked by the SARS outbreak, an economic downturn that dented the developmental myth of Hong Kong as a money market and, most importantly, saw massive popular protests against attempts to introduce anti-subversion laws (the notorious Article 23). For Lee, and many other 20-somethings, however, the real catalyst was the movement to preserve Central's Star Ferry Pier, in 2006.

In August 2006, Lee and a group who came to be known as 'We Are Society' began to stage weekly performances and installations at the pier, later joined by teaching artist Kith Tsang Tak-ping and his students from Polytechnic University. They hoped to raise public awareness of the government's decision to demolish the 1950 s pier despite heritage reports noting its significance in public memory and the potential for an outcry. ${ }^{47}$ While other political and conservation organisations attempted to negotiate with the government and then to apply legal pressure, as Lee has

45 ibid., 129

46 Debate surrounding the definition and legacy of the Post-80s continues in Hong Kong. See Gary Wong Pui-fung and Yuk Hui eds, Pre-\& Post-80s: Beyond Social Movements—Imagining Discourse and the Generation (Hong Kong: Roundtable Synergy Books, 2010).

47 Cartier, 'Culture and the City: Hong Kong, 1997-2007', 76. 
observed, the Post-80s group deliberately chose direct action, stressing the personal concern they felt for what was at stake, and hence the need to represent themselves rather than waiting to be represented by others. ${ }^{48}$

In her article reflecting on cultural and urban development in the first decade since Hong Kong's handover to Chinese rule, Carolyn Cartier describes attending the protest site just prior to the final closure and demolition.

[T] he entrance to the piers had been boarded up, and cultural activists had mounted placards, information boards and banners all around ... in the middle of the roadway where taxis had queued, was a young woman sitting on top of a high ladder, dressed in taut black, looking towards the clocktower. Scissors in hand, she intermittently and methodically cut off pieces of her hair and gave them to the cold breeze. Police stood by and watched; news camera crews filmed her and bystanders with digital cameras put them on movie mode. She was having a mesmerising effect, her silent performance speaking to Hong Kong people: the loss of the Star Ferry piers is deeply personal, like losing a piece of yourself. ${ }^{49}$

Even as the Star Ferry pier was being finally closed and demolished in December 2006, protestors, no doubt buoyed by public support, vowed to take the fight to the nearby Queen's Ferry Pier, slated for a similar fate in April of the following year under the government's reclamation project. Attempts were made to legally challenge the government's position on demolition as the only feasible option. Yet, while the high court eventually ruled in the government's favour and police evicted the remaining protestors (some of whom had begun a hunger strike), the Post-80s had already coalesced, invigorating the pre-existing groups of social actors and inspiring new ones. By the time of the Queen's Ferry action, a certain pattern was emerging: young activists occupied the site, draping banners and tents over the building, while also hosting various creative events in situ, all well documented by the media, the participants and passersby. Meanwhile veteran activists, pan-democrat politicians and experts (e.g. conservationists and architects) pointedly questioned the government's claim of lacking viable alternatives to demolition, evidently

48 Transcript provided by Lee Chun Fung, from his presentation 'We Wanna Make a Change: Art and Social Actions of the Post-80s Generation', presented on 29 May 2011 in 'Backroom Conversations: Open Platform', hosted by Asia Art Archive for the 2011 Hong Kong Art Fair.

49 Cartier, 'Culture and the City: Hong Kong, 1997-2007', 77. 
inspired by the Post-80s' new style of protest. ${ }^{50}$ Eventually, some of the young protestors launched a hunger strike, but all were soon forcibly removed by police for 'illegal obstruction'.

Again in late 2009, when the government had begun to demolish parts of Choi Yuen village, in New Territories, to make way for a high-speed rail link ${ }^{51}$ — which will terminate in the West Kowloon Cultural District development-a loose yet sizeable coalition of art workers, activists and Post-80s (many of whom had taken part in actions to preserve the Star and Queen's Ferry piers), gathered in support of the village. Some Post-80s formed the 'Post 80s Anti-High Speed Rail' group. Apparently inspired by the protests of Korean farmers against the World Trade Organization in 2005, they staged a Tibetan-style single-file walk through five districts, silently pacing, with rice in their hands, prostrating themselves in the winter wind every 26 steps, as they wove their way towards the building of the Legislative Council in the centre of downtown Hong Kong. ${ }^{52}$ Later, back in Choi Yuen, organisers coordinated with local villagers to stage a two-day festival amid the half-demolished buildings, which became site-specific installations (including a photography show of the Post-80s walking action), ad hoc museum displays, public sculptures, as well as stages for literature readings and music concerts. Films were screened and homemade snacks were sold by volunteers, in what was dubbed 'Choi Yuen Tsuen Woodstock: An Arts Festival among the Ruins', a defiant display of grassroots cultural solidarity. ${ }^{53}$

One particularly important focus of Lee's artistic and curatorial work has been the history of the June Fourth protests in Beijing and subsequent crackdown, a topic that is both near and far from Hong Kong. On the

50 For instance, veteran 'leftist' activist Leung Foon, from the Society for Community Organisation (established in 1972), comments on this intergenerational relationship in 'West Kowloon and Star Ferry Pier', in Iman Fok ed., Our Life in West Kowloon (Hong Kong: Society for Community Organisation, 2007), 31-5. Also see Wong and Yuk eds, Pre-\& Post-80s: Beyond Social MovementsImagining Discourse and the Generation.

51 Officially known as the Guangzhou-Shenzhen-Hong Kong Express Rail Link, dubbed 'XRL', constructed by the MTR Corporation, in 2011 the project was already accused of being an unjustified public expense at HKD67 billion; whereas in 2015 this has risen to an estimated HKD85.3 billion. See www.expressraillink.hk/en/project-details/key-information.html. Accessed 18 December 2015.

52 Valerie C. Doran, 'Viewed From a Train: Glimpses of the Artist as Hong Kong Citizen', Perspectives (Asia Art Archive Newsletter), March 2011, www.aaa.org.hk/Diaaalogue/Details/977. Accessed 20 September 2013. The village's support group also produced a two-hour documentary film about the movement, Raging Land: Breaking New Ground Through Thorns and Thistles [ 鐵怒沿線一 華路藍樓 Tienu yanxian - bi lu lan lou] (Hong Kong: V-artivist and Supporting Group of Choi Yuen Village, 2010), DVD.

53 Doran, 'Viewed From a Train'. 
one hand, on 1 July every year a march is held in memory of the event, the first of which, in 1989, remains the largest collective public action in Hong Kong's history. However, Lee has been acutely aware of not having personally experienced June Fourth at the time, given his age. Unlike an older generation, which remembers the scenes on the news and took part in that first march, some Post-80s like Lee have actively sought to form their own knowledge of and relationship with this history. ${ }^{54}$ To mark the 20th anniversary of June Fourth, in mid-2009, just prior to the establishment of Wooferten, Lee and colleagues from We Are Society organised 'P-at-riot', a project held at the Cattle Depot Artist Village, comprising exhibitions, performances and discussions to not only commemorate the anniversary of June Fourth but also to probe each participant's relationship to the event and its memory in Hong Kong. A statement from exhibition materials remains a significant reflection on the relationship of the Post-80s to such events, and their tendency to search for their own answers:

Twenty years have passed, and we have now grown up. In our eyes, June 4th is not just a historical incident that is waiting for vindication, it is an attitude which should be passed on to the next generations. In discussing June 4th, we have decided to move from melancholy (perhaps, a melancholy which could not be totally genuine). What we should bring up again here is the attitude of rethinking about the current situation as well as the gesture of standing out for the truth.

An anecdote about the origin of the name We Are Society aptly explains this different attitude among recent social activists and artists in Hong Kong, who identify more readily as 'the people'. Jasper Lau has explained that the name derives from the 1982 film Nomad (directed by Patrick Tam Kar Ming). When Cecilia Yip's character asks, 'What have we ever contributed to society?', Leslie Cheung retorts, 'What do you mean, society? We are society'. ${ }^{55}$

54 Anecdotally, a number of Hong Kong artists I have spoken to born in the 1960s, who were in their early to late 20s at the time, recall the 1989 march as their first (and, in many cases, until recently, their only) direct involvement in public actions-despite recognising that June Fourth left them more aware of politics or current affairs. See for example Olivier Krischer, 'Wilson Shieh: Political Avatar', Wilson Shieh ... Sumbody (Hong Kong: Osage Gallery, 2013), 33-48.

55 Jasper Lau Kin-wah, 'Tipping Over: Of Politics of Aesthetics as Hong Kong Demands our Art Activism', Art Critique of Taiwan ACT 47 (2012): 75, note 2. 
In early 2011, after returning from a residency at Tokyo's 3331 Arts Chiyoda centre, Lee had the idea to launch a residency programme through which, on a shoestring budget, Wooferten would host six artists and events between 2011-12, focused on guests who used their creative work as a method of social action. From Tokyo, Lee invited Ichimura Misako 市村美佐子, who lives as a homeless person in Tokyo's Yoyogi Park. Ichimura (a graduate of Japan's prestigious Tokyo University for the Arts) had become interested in squatting after a short stay in Amsterdam in 2002, and soon decided to move onto the streets after returning to Japan. From this position she shares the experiences of fellow homeless people, particularly women. One initiative was to start a 'barter café' with fellow resident Ogawa Tetsuo in the blue-tent village where they lived, as a place where homeless and non-homeless could meet without the need for money. Ichimura has also become involved in causes related to the use of public space, such as the long protests to stop the privatisation of Miyashita Park in 2008-10, mentioned above. ${ }^{56}$ Ichimura brought documentation from this protest to Hong Kong during her residency and organised a meal in a nearby small park, which included distributing food to anyone passing by. During her stay she tried to connect to local homeless people, to compare their situation with hers in Japan, and produced a series of photographs in which she lies down comfortably on local park benches, defying their intentionally anti-homeless designs, a common feature of gentrified urban public spaces worldwide. ${ }^{57}$

56 Tetsuo Ogawa 小川哲男 (trans. Chen 'Nine Zero' Jiong-lin), 'The Resistance of Miyashita Park Art Village' 宮下公園藝術村的抗爭 [gongxia gongyuan yishucun de kangzheng], in Yuk Hui and DOXA Collective eds, Creative Space: Art and Spatial Resistance in East Asia (Hong Kong: Roundtable Synergy Books, 2014), 164-79.

57 See Olivier Krischer, 'Lateral Thinking: Activist Networks in East Asia', ArtAsiaPacific 77 (2012): 99; also Misako Ichimura, 'Subversion in Parks and Streets', Wooferten's Art/Activist in Residence (AAIR) 2011-12 (Hong Kong: Wooferten, 2014), 97-101. 


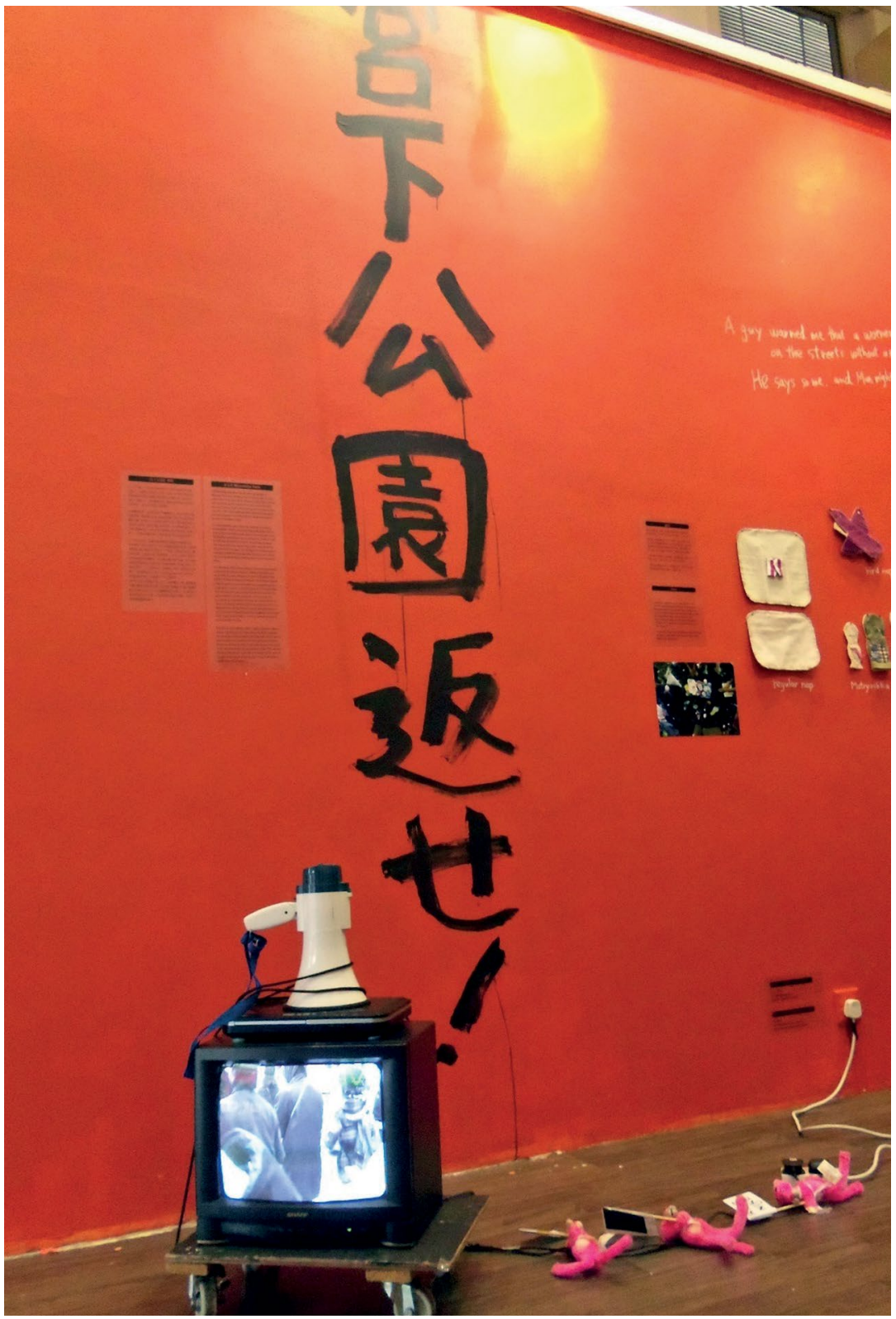

Figure 10: Installation view of Ichimura Misako's 'Homeless Artist' exhibition at Wooferten, August 2011. The slogan on the wall reads 'Hands off Miyashita Park!', referring to the ultimately unsuccessful protests by Ichimura and colleagues to save Tokyo's public Miyashita Park from private commercial development by the Nike Corporation.

Source: Courtesy Ichimura Misako and Wooferten. 
The residency was also a way to build a regional network for Wooferten, connecting between locales rather than official agencies in first-tier cities, which is the typical formula for 'international' cultural projects. Lee had been introduced to Ichimura through a Korean artist-activist colleague, Kim Kang. Kang had been invited to Hong Kong in July of that year, with her collaborator and partner Kim Youn Hoan, and they led squatting workshops. Like Ichimura, Kim Kang had experienced squatting in Europe, in her case in France where she had written a postgraduate thesis on the subject. When she returned to Korea, the pair organised 'Oasis Project', targeting a building owned by Korea's largest arts association, the Federation of Artistic and Cultural Organisations of Korea, established in 1961, which has enjoyed close ties with successive conservative governments during its 50-odd year history. In 1994, the federation lobbied for funding to construct a 25-storey high-rise building in the centre of Seoul, ostensibly for artist use. By 2004, the project was still incomplete, apparently because government-allocated funds (around KRW16.5 billion, or USD14.8 million) had been redirected by the association, and also due to disputes with the contracted construction companies. The Kims argued that, as artists, this prime piece of Seoul real estate was intended for their use, so they went about organising a wellpublicised squat event in which they stormed the building, with media in tow. While the federation claimed the whole project was illegal, the media attention ultimately led to an investigation and to charges relating to the federation's misuse of funds.

When Oasis Project came to an end in 2007, the Kims formed Lab39 with like-minded colleagues to investigate issues of government use of public land, producing a number of research reports. They moved into an area of Seoul known as Mullae-tong, at that time one of the few remaining light industrial areas of small-scale workshops, flanked by apartment complexes. They encouraged fellow artists and musicians to move into the area, which meant negotiating individual leases, but soon well over 100 artists had relocated. Cafes and music venues quickly popped up, even as the steel workshops continued trading. For their 2011 Hong Kong residency, the Kims adapted their project 'Squat Geography Information System (SGIS)', holding workshops to form a database of potential Hong Kong squatting sites, then undertaking an inspection of some, such 
as the former Oil Street Artist Village. They also documented the process of scaling the fence and symbolically 'reclaiming' this once vibrant public building. ${ }^{58}$

\section{A History for Social Movements in Hong Kong}

Through the memorialisation of June Fourth as public memory, and through the development of activist residencies connecting Hong Kong urban issues to those of other metropolises in the region, Lee and Wooferten colleagues have bridged historical and national frontiers, and have reconnected with and created alternative narratives of identity and history in Hong Kong. In some cases, Lee has been surprised to discover the hidden resonance between contemporary and historical sites of social action-an example of which I will return to below. Many historians have marveled at the apparent social stability of colonial Hong Kong, described by some, for example, as an 'administrative absorption of politics' ${ }^{59}$ As history was often commissioned by the ruling authority or its allied elites, alternative narratives have surfaced only recently. Hong Kong's unique situation of 'decolonisation without independence' makes instances of anti-authoritarian action, even those that appear nationalistic, remain historically sensitive. Yet, even before 1997, social movements shaped politics and local identity in a variety of ways that, while distinct from the contemporary situation, nevertheless deserve to be rediscovered as parts of a longer historical arc through which to understand life politics in Hong Kong.

While the 1940s-50s saw labour strikes and reflections of the Chinese civil war, the watershed moment in postwar Hong Kong social movements was the so-called Kowloon riots of 1966-67. Most notably, the riots seem, in hindsight, to have prompted far-reaching policy shifts in the late 1960s and 1970s, through which the colonial administration invested more

58 Olivier Krischer, 'Lateral Thinking: Activist Networks in East Asia'; Kim Kang and Kim Youn Hoan, 'S.G.I.S. in Hong Kong', Wooferten's Art/Activist in Residence (AAIR) 2011-12 (Hong Kong: Wooferten, 2014), 62-67. Part of the site (No. 12 Oil Street, formerly the Royal Hong Kong Yacht Club clubhouse) was renovated and reopened as 'Oi! Oil Street Art Space' in May 2013.

59 Ambrose Y. C. King, 'Administrative absorption of politics in Hong Kong: emphasis on the grassroots level', in Ambrose Y. C. King and Rance P. L. Lee eds, Social Life and Development in Hong Kong (Hong Kong: Chinese University Press, 1981), 129. 
earnestly in the recognition and enrichment of the local quality of life. Projects such as the highly effective Independent Commission Against Corruption (1974), the underground Mass Transit Rail system (1979), ${ }^{60}$ even the recognition of Cantonese as an official language (1974), all date from this period and are now perceived as integral parts of local identity, generating notions such as rule of law, technology and efficiency, and Hong Kong as bastion of Cantonese heritage.

It is not my intention to claim that these riots raised the quality of Hong Kong life during the 1970s. Rather, my aim here is to deepen the context of contemporary social movements by showing the complex relationships that exist with earlier issues and sometimes even particular sites. The 1966 incident, for instance, was directly triggered by opposition to a fare increase on the Star Ferry, which escalated from general complaints and petitions when one man launched a hunger strike and openly clashed with the authorities, leading to wider protests, government repressions and then rioting. ${ }^{61}$ Barely a year later, in May 1967, a series of labour disputes came to a head when 21 workers at a plastic flower factory in Kowloon clashed with police. ${ }^{62}$ Within days the communist-dominated Hong Kong Federation of Trade Unions stepped in, and then on 15 May the Chinese Government made an official statement of protest to the British Embassy in Beijing. Anti-British demonstrations were staged in Beijing and Guangzhou, backed by Peoples Daily editorials, which reframed the disputes as an anti-colonial movement-echoing aspects of China's own ensuing Cultural Revolution. Seizing on this tacit endorsement, Hong Kong communists and leftist sympathisers initially launched anti-colonial demonstrations, strikes and propaganda campaigns; but when, by August,

60 While the first MTR line was opened in 1979, construction had begun in 1967, based on a government-commissioned study on alleviating traffic congestion.

61 Tai-lok Lui and Stephen W. K. Chiu, 'Social Movements and Public Discourse on Politics', in Tak-wing Ngo ed., Hong Kong's History: State and Society Under Colonial Rule (London; New York: Routledge, 1999), 104.

62 The factory was in fact owned by Li Ka-shing, then a young businessman, now one of Asia's wealthiest people, with influential stakes in all major aspects of Hong Kong life and beyond, including shipping, real estate, retail, communications and utilities. He is generally considered one of the most powerful figures in Hong Kong's capital-orientated political landscape. 
the administration shut down leftist newspapers and launched raids and arrests, some leftists started a violent bombing campaign that lasted till October. ${ }^{63}$

Hong Kong was for many a safe haven from decades of uncertainty and conflict in China, memories easily rekindled by the Cultural Revolution. Rather than inspiring anti-colonial solidarity, such leftist violence had the opposite effect, radicalising anti-colonial politics to the point of alienating its intended constituency. The colonial administration quashed leftist agitators and quickly worked to bolster confidence in the government. The riots failed to open new channels of political participation, but they did draw attention to social issues such as labour conditions, access to housing and social services, which would inform both new government policies and grassroots pressure groups in the decade to come. In effect, 'politics had now been localised': ${ }^{64}$ there was a shift from ideological 'Chinese politics' to more spontaneous, issue-driven actions, whichgiven the lack of political access inherent in the colonial 'consultative democracy' model —made protests the medium of local grievances. ${ }^{65}$

While Communist China may have been rejected, this did not equate to an increased identification with the colonial regime. For a younger (by then often Hong Kong-born) generation during the 1970s, the search for a new cultural identity even extended into an interest in cultural nationalism, exemplified in the 'imported' issue of the Defend Diaoyutai Movement. ${ }^{66}$ In parallel, between 1950 and 1980, the colonial government gradually implemented stricter controls on immigration, introducing a 'Hong Kong Belonger' classification from 1971, which seemed to positively identify local identity, albeit as an offshoot of essentially exclusionary

63 Robert Bickers and Ray Yep eds, May Days in Hong Kong: Riot and Emergency in 1967 (Hong Kong: Hong Kong University Press, 2009), 6-11. In preparation for May Days in Hong Kong, the editors organised a public forum on the riots in 2007, testimonies from which are included at the back of the book. Some who had witnessed or participated in the riots spoke of the experiences for the first time in nearly 40 years. In their study of social movements in Hong Kong, Lui and Chiu note there were no publicly available records documenting the experiences of riot participants, providing instead excerpts of a 1996 interview suggesting that non-communist students, many of them barely teenagers, had been mobilised, for example to print and distribute leftist anti-colonial materials, and were subsequently arrested by the authorities despite their young age. See Lui and Chiu, 'Social Movements and Public Discourse on Politics', 116, note 20.

64 Lui and Chiu, 'Social Movements and Public Discourse on Politics', 105.

65 Lui and Chiu, 'Social Movements and Public Discourse on Politics', 102.

66 Lui and Chiu, 'Social Movements and Public Discourse on Politics', 108. 'Defend Diaoyutai' refers to the movement to assert China's territorial right to the disputed islands known as Daioyutai in Chinese and the Senkaku Rettō in Japanese. 
immigration policy shifts in the United Kingdom. This began to formalise distinctions between locals and newcomers in the face of ongoing, though more regulated, Chinese immigration. In 1980, the government assumed complete control of immigration. In her study of identity formation in relation to immigration policy, Agnes Ku has pointed out the multiple factors that contributed to identity formation in Hong Kong during this period, which include but are not limited to demographic shifts, distinction from Communist China amid the Cold War, community formation in the face of economic and social crises (such as the 1967 riots, or later the arrival of Vietnamese boat people), adherence to economic liberalism and rapid growth, or demographic shifts. ${ }^{67}$ What is clear, however, is that the issue of Hong Kong identity was still shifting and unresolved when the colonial government formally embarked on the handover process in 1984.

In the period between the Draft Declaration of 1984 and the 1997 handover, expectations regarding political participation also significantly changed in Hong Kong. Beijing was perhaps unprepared for such a shift and largely interpreted demands for greater democratic participation as the result of British intervention in what would otherwise have been a smooth transition of sovereignty from the colonial administration to a Beijingstamped bureaucracy of public servants with decades of local experience. Since then, at the heart of most large-scale protests have been the issues of state-capital collusion and a lack of equitable representation in the SAR's functional constituency model-most spectacularly in the recent so-called Umbrella protests, which initially rallied not for 'democracy', but the rather more concrete demand for 'real elections' (i.e. universal suffrage). Seen in this light, recent informal actions can be related to farreaching issues of not only political representation, but more nuanced questions of local identity and values.

67 Agnes S. Ku, 'Immigration Policies, Discourses, and the Politics of Local Belonging in Hong Kong (1950-1980)', Modern China 30, no. 3 (July, 2004): 328. 


\section{Post-Wooferten Postscript}

From late 2013, the Arts Development Council informed Wooferten that its application for the coming year would not be approved. Lee and colleagues decided to occupy the space and they launched a media campaign to encourage debate around the closure. While the cyclical nature of ADC grants had not been surprising, they wished to draw attention to the unique position they had forged in the local community. There was a distinct irony in the way a multibillion dollar project such as the WKCD could be mired in a lack of public relevance, while a small space that worked hard to understand and be understood by its existing local community could be unceremoniously shut down. They have since formed the Wooferten Working Group to continue their activities, and through this they maintain a regular social media presence. In January 2014, with their eviction imminent, I received an upbeat email message from Lee Chun Fung, in which he noted:

In fact, I think once we want to keep on doing something with the community we have no need to worry about not having a space to do it. And I don't need many resources either. We will do it in a more autonomous way, I'm quite confident about that. Hong Kong is an interesting place [now] because there are many artists concerned about their community. Most important is to sustain the network and keep on. That's just the very beginning. ${ }^{68}$

Lee's comment is reminiscent of Melucci's notion of the new social movement as an action network. Many art spaces and groups that have emerged in protests and social actions have since dispersed, but the individual artists and activists continue to share the same concerns, albeit looking for different means to articulate and act on them. Some have turned to full- or part-time farming, others to education, still others have altogether distanced themselves and their artwork from the flurry of protests. Some young artists have gone on to join longer-standing organisations engaged in urban and social research. I know one artist who has also begun intense research into religious art, setting aside his conceptual practice in the search for 'spiritual' responses to contemporary flux. In the same email conversation, Lee also wrote: 'To me, art never

68 Lee Chun Fung, email correspondence with author, 9 January 2014. 
changes something directly. What's important is that art gives us a platform for joining together, to try to understand issues from an alternative angle, in a sustainable, intimate and subversive way. ${ }^{69}$

In a more recent trip to Hong Kong, I learnt of a performance organised by Wooferten in the months after this conversation. With the space's fate apparently sealed, Lee and colleagues had nevertheless continued their work, combining their art and politics with the context of the community they had nurtured. In May and June 2014, they held two street performances near the Shanghai Street space that exemplify the complicated way in which informal life politics can affect history, identity and community. The performances were based on documentary research into a largely unknown incident forming a historical link between the Beijing protests of June 1989 and Hong Kong. Titled 'Back to 6.7.89: Pitt Street Riot-Rolling Theatre of Tiananmen Massacre', the event comprised reenactments and scripted reminiscences of 7 June 1989, just days after the news from Beijing had rocked Hong Kong. That night, on Pitt Street in Yau Ma Tei-barely 100 metres from the Wooferten space-a 'riot' had erupted; more than 7,000 people gathered, projectiles were thrown, cars were torched and looting occurred. Police bused into the scene fired 19 rounds of tear gas. One effect of this public disturbance was the cancellation of a massive rally commemorating the Beijing massacre, planned for the following day, which organisers estimated would have attracted 1.5 million people to the streets. Through this combination of street theatre and citizen history, Lee and others sought to unearth and reconnect to these missing memories and ask (as Rancière might put it), what if: What if the protest had taken place? What if we knew more about this riot, as a direct consequence of the Tiananmen protests in Hong Kong? How would the course of Hong Kong's history change? How does this change the history and possibility of protest in Hong Kong? ${ }^{70}$

69 Lee, email correspondence with author, January 2014

70 A booklet and DVD have been produced documenting the event and this history, including short reminiscences from Yau Ma Tei locals. See Pitt Street Riot - Rolling Theatre of Tiananmen Massacre Video \& Documents [碧街事件一六四滾動街頭劇場行動紀錄 Bijie shijian - liusi gundong jietou juchang xingdong jilu], edited by Lee Chun Fung (Hong Kong: Wooferten Kai Fong Wui, 2015). A selection of film clips and essays have also been collected on the project's website, to allow wider access to history of this incident: pittstreetriot.blogspot.com.au/2015_05_01_archive.html. 


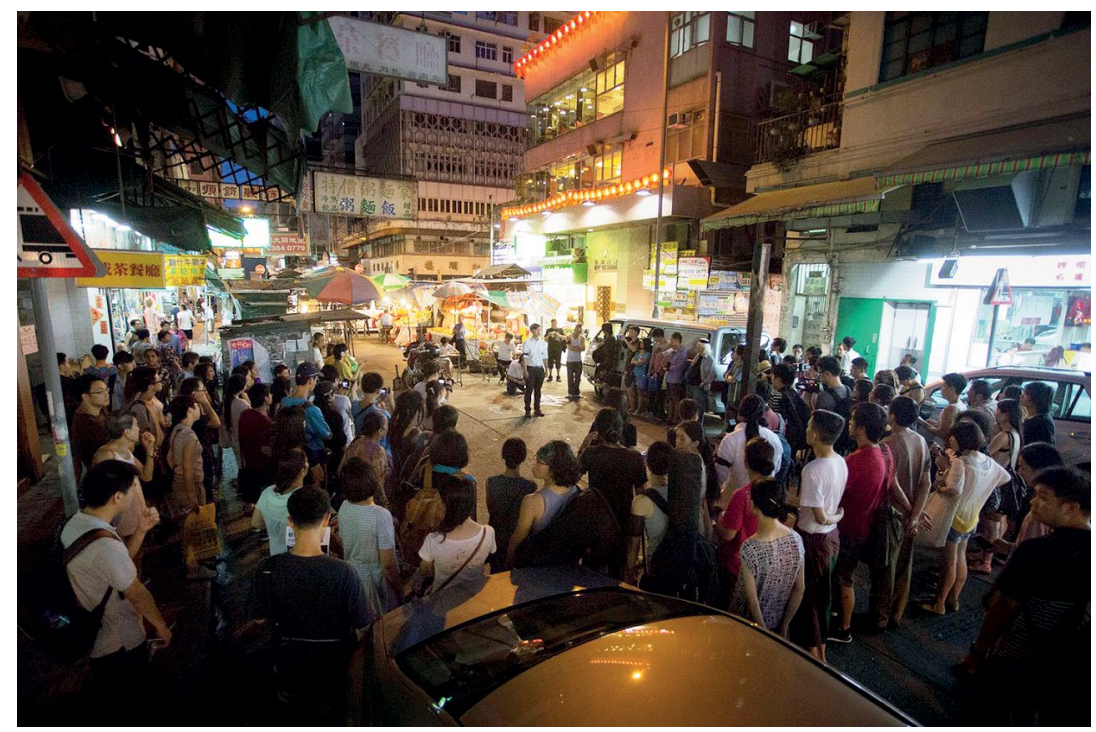

Figure 11: Performance still of the 'Back to 6.7.89 Pitt Street Riot - Rolling Theatre of Tiananmen Massacre', staged in Yau Ma Tei, Hong Kong, on 31 May and 7 June 2014.

Source: Image by Pak Chai; courtesy Lee Chung Fung.

In Lee's essay for the project titled 'Yesterday is Today but Also Tomorrow', he writes that the subject of this theatre was a 'missing' history, the story of this dramatic episode in Hong Kong's history of collective public action that has never been retold. Beyond immediate questions of social and economic injustice, many cases in which informal life politics take place similarly deal with missing or belated histories being sought out and retold. Given the proximity to Wooferten, and their relationships in the neighbourhood, Lee and his colleagues' 'research' consisted of interviews with neighbours, most of whom had not had the chance to discuss these events for over 20 years. Lee's own reflection on this unearthed history, then, is not only for the incident itself but rather its dormant and still potent legacy: the way it has sat silently in the hearts of a community until now. ${ }^{71}$ Lee has actually noted how an experienced social worker friend of his once quipped that Wooferten, in its community centre approach, hadn't discovered anything, it was merely recreating the sort of community space in which their grandparents' generation would have

71 Lee Chun Fung, 'Yesterday is Today but also Tomorrow', in Pitt Street Riot (2015), 22-3. 
once congregated. ${ }^{72}$ Ideally, these were spaces in which the community was enacted, confirmed and reconstituted, acting as meeting places and forums to share concerns, histories and resources.

Wooferten's work has been an experiment in art and politics, but also many related facets of the community that the original members could not have foreseen-local history, identity, urbanisation, gentrification, labour rights, migrant workers and regional activism. In this chapter, I have situated creative social activism in Hong Kong in a broader history of social actions and cultural politics in Hong Kong. Melucci's work also alerted us to the need to recognise the limitations of existing discourse, and this remains vital if we are to recognise the kind of 'action networks' in which Wooferten work. The pressure of existing discourses always has the potential to radically redefine events. For example, just months after the Pitt Street Riot theatre piece, from late September to December 2014, the Umbrella movement occupied the streets of Hong Kong. Yet even before the last defiant occupiers had been evicted one last time from the streets, popular discussion turned immediately to the old dichotomy of success and failure. Had the movement been a success for mobilising so many diverse groups into direct, generally coordinated and incredibly sustained action? Or was it all ultimately a failure, since C. Y. Leung's government had managed to weather the storm, refusing to meet the movement's core demand of universal suffrage and, perhaps more importantly, since the movement had seemingly failed to maintain public support?

This chapter argues that the very nature of politics is to transgress such dichotomies, and this is typical of the examples of informal life politics we see practised here. Rancière's notion of creative transgressions is also useful in considering the relationship of art and politics in Wooferten. A final anecdote from Wooferten's 'Small Small Prize! Big Big Pride!' project succinctly intervenes in the question of art or politics. Lee Chun Fung recalls an episode in which one of the Yau Ma Tei locals, reflecting on the rapid changes in the community, suddenly burst into tears. Lee later observed:

72 Lee Chun Fung 李俊峰, 'Cong bashihou de guandian kan huohuating' [Wooferten, seen from a Post-80s Perspective], 222. 
The reason she was crying was, on the one hand, the community was changing so quickly she couldn't help but forget; but on the other hand, because we were actively caring about this old district's past, it prompted her to suddenly reminisce. At that moment, it didn't really seem to matter where the 'art' was. ${ }^{73}$ 
This text is taken from New Worlds from Below: Informal life politics and grassroots action in twenty-first-century Northeast Asia, edited by Tessa Morris-Suzuki and Eun Jeong Soh, published 2017 by ANU Press, The Australian National University, Canberra, Australia. 